Article

\title{
How Organizational Citizenship Behavior Affects ERP Usage Performance: The Mediating Effect of Absorptive Capacity
}

\author{
Kee-Young Kwahk ${ }^{1}$, Sung-Byung Yang ${ }^{2}$ and Hyunchul Ahn ${ }^{1, *(1)}$ \\ 1 College of Business Administration, Kookmin University, 77 Jeongneung-ro, Seongbuk-gu, Seoul 02707, \\ Korea; kykwahk@kookmin.ac.kr \\ 2 School of Management, Kyung Hee University, 26 Kyungheedae-ro, Dongdaemun-gu, Seoul 02447, Korea; \\ sbyang@khu.ac.kr \\ * Correspondence: hcahn@kookmin.ac.kr; Tel.: +82-2-910-4577
}

Received: 14 April 2020; Accepted: 25 May 2020; Published: 1 June 2020

\begin{abstract}
Enterprises have implemented enterprise resource planning (ERP) systems as a strategic vehicle to gain a competitive edge. However, such ERP systems do not always guarantee successful results. While ERP systems may provide an organization with numerous benefits, they can also destroy a business if not successfully adopted, owing to enormous investment losses coupled with low business efficiency. To explore a way to reverse this situation, we examine how organizational citizenship behavior influences the successful management of ERP systems. Moreover, the mediating role of absorptive capacity in this relationship is investigated. The empirical analysis results, based on 188 surveyed organizations in Korea, reveal a partial mediating role of absorptive capacity on the relationship between organizational citizenship behavior and ERP usage performance. The findings of the study shed light on the ways of how the companies that adopt ERP systems to facilitate ERP usage and to gain business sustainability.
\end{abstract}

Keywords: ERP usage performance; organizational citizenship behavior; absorptive capacity; knowledge management; mediation effect

\section{Introduction}

The business environment has been rapidly changed due to the advancement of information and communications technology (ICT) and information systems (IS). Enterprises have responded to this rapid change by implementing an enterprise resource planning (ERP) system as a strategic tool. One study revealed that most large enterprises all over the world have already been using ERP systems for several decades [1]. Recently, many small and medium-sized enterprises (SMEs) are trying to adopt ERP systems to gain competitiveness advantage [2]. However, the integration of ERP systems with legacy systems entails organizational changes, as well as business process reengineering, resulting in many potential risks. As a result, $55 \%$ to $75 \%$ of all ERP projects are known to fail to achieve their goals [3].

A great deal of research has tried to identify the factors resulting in the success or failure of implementing ERP systems. Among such influencing factors, some researchers have focused on sharing and utilizing knowledge, as well as the absorptive capacity of the organization's members [1,4]. Davenport (1998) [5] revealed that a lack of knowledge sharing and use could lead to such failure. Soh et al. (2000) [6] also found that the gap of knowledge among the end-users, IS staff, and ERP vendors is the key factor that caused the failure. Their study highlighted the successful integration of the knowledge from the aforementioned stakeholders. As the majority of enterprises that have introduced and operated an ERP system have received help from external consultants with regard 
to the development and implementation of such ERP systems [7], it is necessary to ensure that the knowledge provided by these consultants is successfully transferred to those within the enterprise who will make use of ERP systems [6]. Even in cases where knowledge and best practices may be present within an enterprise, the effective transfer of knowledge cannot take place if individual members do not possess the necessary absorptive capacity. In this regard, Shang and Hsu (2007) [1], Nwankpa (2015) [8], and Marabelli and Newell (2019) [9] suggested that the successful introduction of an ERP system was closely related to absorptive capacity.

The sharing of knowledge can be perceived as relationships of social exchange. As in the case of economic exchanges, exchange behaviors related to social exchanges are based on expectations for future compensation. However, social exchanges do not precisely represent future responsibilities or rewards, unlike economic exchanges. Here, organizational citizenship behavior (OCB) can be considered as an individual behavior that emerges from the social exchange relationships [10]. OCB refers to a person's voluntary behavior within an organization that is not part of his or her contractual tasks and responsibilities. It includes active communications and voluntary interactions among individuals in an organization. Such communications and interactions are based on the social exchange relationships. The lack of such active communications and voluntary interactions derived from OCB weakens the individual's absorptive capacity and inhibits knowledge sharing in the organization [11].

With the motivation mentioned above, this study undertook the following tasks. First, a theoretical model that delves into the relationships among OCB, absorptive capacity, and ERP usage performance was established and verified. Second, an attempt was made to ascertain whether or not absorptive capacity can effectively mediate the relationship between OCB and the usage performance of ERP systems. Understanding the effect of OCB and absorptive capacity on ERP usage performance will contribute to an increase in the success rate of ERP adoption. In particular, examining whether absorptive capacity plays a full or partial mediation role in the relationship between OCB and ERP usage performance will help us to precisely understand the mechanism on how OCB affects ERP usage performance. If absorptive capacity plays a full mediation role, the effect of OCB should be recognized solely as an antecedent factor of absorptive capacity. Otherwise, both the direct and indirect effects of OCB should be considered when explaining ERP usage performance. Thus, the findings of this study can shed light on the ways that organizations facilitate their ERP usage performance from a knowledge management perspective.

The remainder of this paper is organized as follows. Section 2 introduces the concept of OCB and absorptive capacity, and their sub-constructs proposed in the previous studies. Prior studies that have explored the effects of OCR and absorptive capacity on ERP usage performance are also examined in this section. Section 3 presents our research model, which proposes the integrated mechanisms of OCB, absorptive capacity, and ERP usage performance. Section 4 explains research methodology, and the next section provides the results from the empirical analysis. Section 6 discusses the findings of the study, and presents academic and practical implications. Limitations and suggestions for future research directions are also provided in the final section.

\section{Theoretical Background}

\subsection{Organizational Citizenship Behavior (OCB)}

Social exchange theory reveals that the interaction between individuals leads to the exchange of non-material artifacts, such as prestige and intimacy, as well as material goods. Based on social exchange theory, relationships are established and maintained among actors with respect to expected rewards [12]. The continuing success of social exchanges depends on the belief that all involved parties will be treated fairly and will benefit equally from the relationship [13]. For a long time, social exchange theory has been served as a base theory for conceptualizing OCB [14]. OCB is defined as "individual behavior that is discretionary, not directly or explicitly recognized by the formal reward system, and that in aggregate promotes the effective functioning of the organization" [10]. It does not imply that individuals engaged in uncompensated behavior do not require any type of reward. Rather, 
it implies that these individuals help others by believing that they, too, will receive help from others going forward. The confidence in this mutually reciprocal relationship promotes individuals to help other members in an organization, which in turn benefits the organization itself.

Smith et al. (1983) [15] identified the dimensions of OCB as altruism and generalized compliance, whereas Becker and Vance (1993) [16] expanded altruism to include both local and distant altruism and re-conceptualized generalized compliance as conscientiousness. Further, Mackenzie et al. (1991) [17] categorized OCB into objective performance, altruism, courtesy, civic virtue, and sportsmanship, while Van Dyne et al. (1994) [18] classified it as loyalty, obedience, and participation. Although the identified components of OCB have varied from researcher to researcher, the five sub-dimensions commonly found in prior studies (i.e., altruism, conscientiousness, courtesy, sportsmanship, and civic virtue) are adopted in our study [15-18].

Altruism refers to the selfless act of helping others deal with task-related problems within an organization. For example, altruism can be regarded as helping colleagues overcome difficulties or helping new workers adjust to the company environment with ease. Conscientiousness refers to the performance of one's job description to meet the minimum requirements, which includes punctuality and behaviors that are in line with the established rules and regulations. Courtesy refers to the mindset in which attempts are made to prevent the emergence of any problems with other workers beforehand. Examples include drawing attention to a particular problem before it surfaces, holding preliminary discussions, and sharing information. Sportsmanship refers to an attitude in which attempts are made to move grievances and complaints that may emerge within an organization in a desirable direction. Examples include pursuing an optimistic outlook by focusing on the positive, rather than what is wrong, and not wasting time on trivial matters. Finally, civic virtue indicates one's participation in organizational activities, based on a clear awareness of one's responsibilities. This includes self-motivated efforts to keep up with all developments within an organization and the act of learning or being aware of the contents of all correspondences and documents.

Realizing the limitations of demonstrating an organization's performance solely using its employees' formal work behaviors [17], researchers have attempted to connect the employees' informal work behaviors, like OCB, to organizational performance. In George and Bettenhausen's (1990) [19] research, OCB was found to mediate the relationship between influencing factors (i.e., leader's positive mood, group cohesiveness, and socialization) and sales performance. Podsakoff and Mackenzie (1994) [20] also conducted an empirical analysis to prove that sportsmanship and civic virtue (sub-dimensions of OCB) influence the sales performance of marketing departments. Morrison (1996) [21] further introduced an OCB model to the service industry, assuming that OCB affects the level of services for customers. In their empirical study, Yoon and Suh (2003) [22] suggested that OCBs, including altruism and sportsmanship, positively influence the quality of services. Chang et al. (2019) [23] found that OCB for the environment significantly affects green product development performance. Stoffers et al. (2020) [24] also found that OCB enhances innovative work behaviors with the partial mediation effect of employability.

\subsection{Absorptive Capacity}

Absorptive capacity is defined as "the ability of a recipient to recognize the importance and value of externally sourced knowledge, assimilate it, and apply it" [25]. Zahra and George (2002) [26] argued that it relates to the ability for acquiring, assimilating, transforming, and exploiting knowledge in the day-to-day value creation process. That is, it can be understood as the outcome of an individual's knowledge transfer for accumulating and sharing his or her learning activities [25]. Active learning enriches existing knowledge; moreover, it strengthens the capacity to make use of novel knowledge and encourages knowledge management activities. These learning activities are derived from exploration, research, or repetitive training [27].

According to Zahra and George (2002) [26], the four sub-dimensions, consisting of absorptive capacity that play major roles in knowledge processing, are acquisition, assimilation, transformation, 
and exploitation. Acquisition refers to the capacity to cognize and learn the knowledge needed to perform the task. Innovation capacity, pertaining to the ability to accept, evaluate, and use external knowledge, is generated through prior knowledge (i.e., basic skills, shared languages, scientific and technological knowledge, etc.) acquired within an organization [25]. Therefore, placing a heavier focus on the acquisition process can enhance absorptive capacity [28], leading to a better adaptation of external technology. Assimilation refers to the capacity to perceive, analyze, and understand the information acquired from external sources [28,29]. Through voluntary learning or education, acquired knowledge requires enough time to be fully processed [30]. Indeed, the acquisition of knowledge inevitably involves a systematic procedure in which efforts are made to internalize new knowledge [29]. Transformation refers to the capacity to combine the knowledge that he or she currently has with the new knowledge acquired and assimilated [26]. This can be regarded as the process of sharing one's acquired knowledge with others, or the process of converting acquired knowledge into personal know-how by combining existing knowledge with external knowledge. The transformation stage, thus, involves the exploration of previously undiscovered external opportunities and the qualitative improvement of transferred knowledge [31]. Finally, exploitation refers to the capacity to use transformed knowledge to create new capabilities to apply it [26]. Cohen and Levinthal (1990) [25] emphasized the importance of knowledge application in reference to absorptive capacity. Kim (1998) [32] further specified exploitation as a problem-solving capability, as well as the ability to generate new knowledge, which can be interpreted as the ability to apply new knowledge to the tasks at hand.

Absorptive capacity has been spotlighted in a wide range of management areas, including IS management [33]. For example, Zahra and George (2002) [26] suggested that enterprises should focus on increasing employees' absorptive capacity, which is an essential factor in successfully adopting new information technology (IT). Francalanci and Morabito (2008) [34] also found that absorptive capacity in an organization plays a mediating role in the relationship between IT and business performance in SMEs. Daghfous et al. (2018) [35] investigated the knowledge transfer process undertaken by suppliers of IT innovations. They found that knowledge transfer initiatives had the minimum threshold level required for initial customers' absorptive capacity in order to be valuable to the suppliers, especially those offering complex IT products or services.

\subsection{Enterprise Resource Planning (ERP) Performance}

Enterprises spend a substantial amount of money implementing ERP systems to increase their operating efficiency, which should result in more profits for companies. Previous research has investigated various factors concerning ERP performance, among which OCB and absorptive capacity are two of the most discussed variables. With regard to the IS field, Lee and Lee (2004) [36] empirically analyzed the effect of OCB on change management, one of the most important topics in terms of ERP systems management. In addition, the positive effects of knowledge assimilation, knowledge application, and knowledge transfer (i.e., the salient sub-dimensions of absorptive capacity) on ERP usage performance were found [31,37]. In their propositional research, Ke and Wei (2008) [38] incorporated a variety of interesting antecedents in testing the consequences of ERP implementation (i.e., an organization's encouragement toward learning self-development, tolerance toward taking risks and making mistakes, constant support and a collaborative working attitude, clear communication among functional groups, power sharing, and collaborative decision-making), all of which contributed positively toward ERP's success. Yoon (2009) [39] further analyzed the influence of OCB on the success of ERP systems; the five dimensions of OCB (i.e., altruism, conscientiousness, courtesy, sportsmanship, and civic virtue) were tested empirically to prove their positive effects on information quality, IT innovation, and work efficiency pertaining to the success of ERP systems. Saraf et al. (2013) [40] found the significant relationships between absorptive capacity and the success of ERP implementation and ERP assimilation, respectively. Moreover, absorptive capacity was found to play a moderating role in the relationship between antecedent factors and ERP assimilation [41]. Mayeh et al. (2016) [42] also analyzed the effect of absorptive capacity on the adoption of ERP systems and found 
that absorptive capacity positively affects perceived usefulness, which in turn leads to the intention to use ERP systems. Nandi and Vakkayil (2019) [43] found that absorptive capacity at the organizational level is partially related to ERP assimilation.

The prior studies described above have explored the relationship between OCB or absorptive capacity and ERP-related performance [31,36-43]. However, there has been little research to investigate the relationships among OCB, absorptive capacity, and ERP usage performance in an integrated framework, and to examine the type of the mediation effect (a partial or full mediation) of absorptive capacity in the relationship between OCB and ERP usage performance.

\section{Research Model}

The research model presented in Figure 1 empirically examines the effect of OCB on ERP usage performance and absorptive capacity, and the effect of absorptive capacity on ERP usage performance. It is also designed to examine the indirect effect of OCB on ERP usage performance via the absorptive capacity of system users. While previous studies have introduced multiple dimensions of OCB and absorptive capacity [15-18,26], this study focuses on the five detailed components of OCB (altruism, conscientiousness, courtesy, sportsmanship, and civic virtue) and the four detailed concepts pertaining to absorptive capacity (acquisition, assimilation, transformation, and exploitation). OCB and absorptive capacity are considered as second-order variables consisting of the five and the four formative first-order variables, respectively.

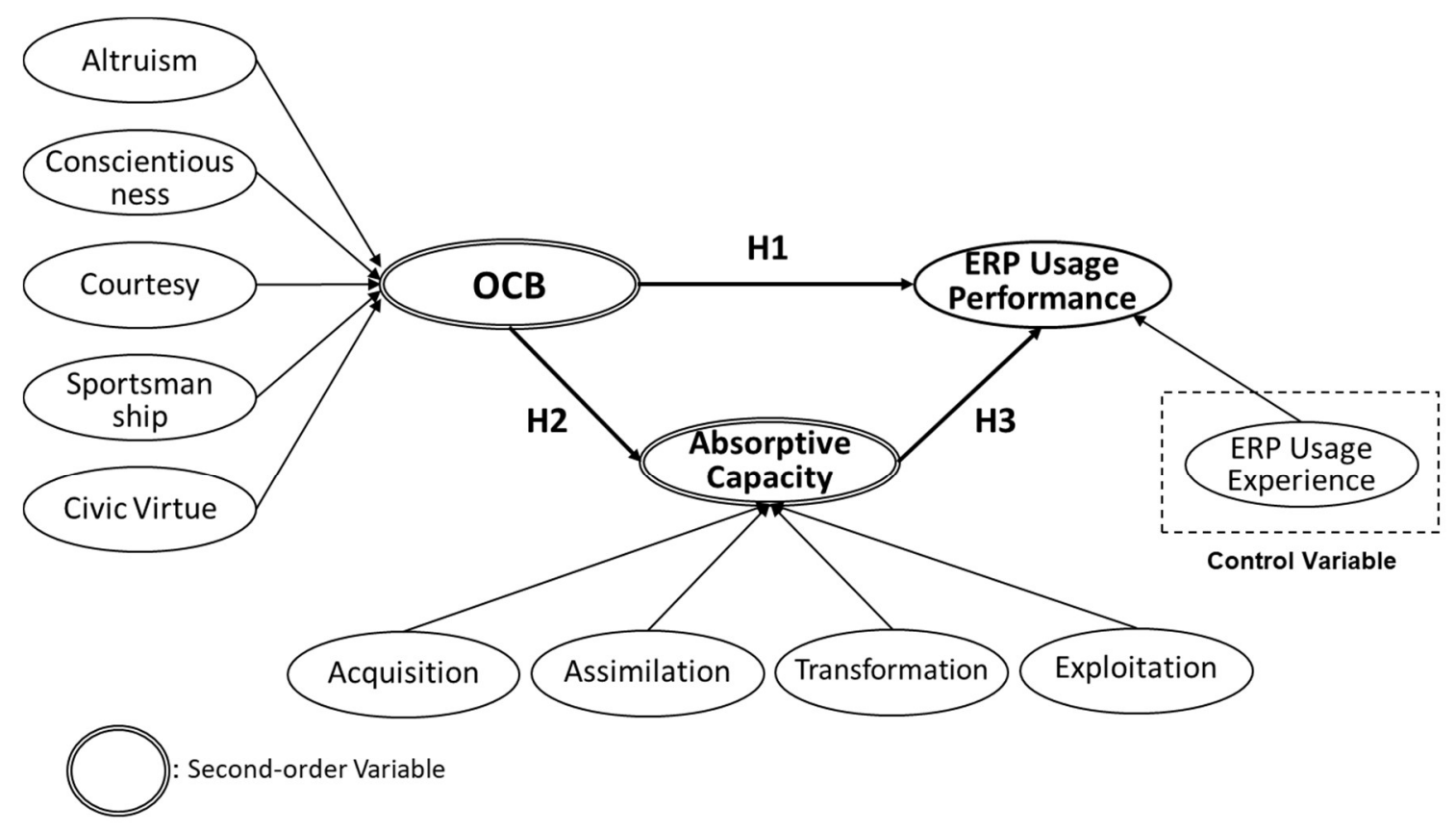

H4: Absorptive capacity exerts a mediating effect on the relationship between organizational citizenship behavior and ERP usage performance.

Figure 1. Research model.

OCB is concerned with individual attitudes toward helping others, such as engaging in altruistic behavior. As mentioned earlier, OCB has been considered as one of the most important influencing factors in realizing ERP performance [36,38,39]. According to Lee and Lee (2004) [36], an ERP user's OCB, as a broad concept, positively influences change management. In addition, various specific sub-dimensions of $\mathrm{OCB}$, such as learning/development culture, conflict/risk tolerance, support/collaboration, cross-functional communication, power sharing, and participative decision-making, were found to influence ERP implementation success by Ke and Wei (2008) [38]. The influencing roles of the five sub-dimensions (altruism, conscientiousness, courtesy, sportsmanship, and civic virtue) of OCB on ERP system success 
have also been proved by Yoon (2009) [39]. Following the results of previous investigations, it is hypothesized that OCB has a positive impact on ERP usage performance.

Hypothesis 1 (H1). OCB is positively associated with ERP usage performance.

Individuals with a higher level of OCB believe in helping others who are challenged with problems. Since these individuals are exposed to a myriad of difficult situations, their learning ability and problem-solving skills will improve greatly. Moreover, the pleasure obtained from the experience of helping others will increase self-efficacy levels, which is a major motivational factor in the field of knowledge management [44], and more specifically, in the dynamics of knowledge exchange and sharing [45]. Since individuals with a higher level of OCB have great affection for their colleagues and organization, they go out of their way to help resolve colleagues' problems. This pro-social behavior engenders trust, approval, and respect from their colleagues, which fosters active social exchanges among organizational members [12]. Intimate social relationships, achieved through the respect and trust of involved parties, perpetuate expressive and instrumental support for one another and precipitate the constant exchange and accumulation of new knowledge. This also improves individuals' ability to absorb external knowledge and assimilate it.

The presence of OCB enhances interactions between organizational members by reducing tensions and miscommunications [46]. Knowledge creation occurs when knowledge derived from dissimilar individuals is integrated and transformed [47]. Interaction capacity, which can be divided into capacities for internal and external interactions, represents the ability of members in an organization to share, develop, and utilize knowledge possessed by the organization. The factors influencing internal interaction capacity comprises internal communications, experience sharing, and leader's involvement [47], whereas the factors influencing external interaction capacity comprises cooperation with suppliers, contact with customers, and communication with external experts [48]. Further, the factors related to internal interaction capacity constitute procedural learning activities, which integrate and recreate different kinds of knowledge, thus influencing its transformation. More interactions within an organization lead to a higher amount of available knowledge. The ability to frequently participate in interactions involves both frequent and direct communications between members in an organization [49]. Informal personal interactions are considered more important than formal interactions with regard to absorbing and creating knowledge [50]. Based on these discussions, it can be surmised that OCB exerts a positive influence on absorptive capacity, leading to the following hypothesis:

Hypothesis 2 (H2). OCB is positively associated with absorptive capacity.

Since the main function of ERP systems is to transfer external knowledge to the appropriate modules within the ERP package, absorptive capacity becomes an important attribute in successfully transferring relevant external knowledge [51]. Additionally, a high level of absorptive capacity is required to effectively utilize the knowledge delivered from an ERP system [26]. Boynton et al. (1994) [52] argued that absorptive capacity affects the use of IT in a positive way. Park et al. (2007) [31] empirically proved that absorptive capacity during the knowledge transfer process positively affects the performance of ERP system use. Recent prior studies have also reported that absorptive capacity plays a significant role in successful ERP implementation (adoption) or ERP assimilation [40-42]. ERP systems are implemented by companies as a strategic tool to gain a competitive advantage. However, to effectively use the ERP system, organization members must perform personal learning activities, such as participating in educational activities or seminars and referencing operation manuals. Therefore, it is safely concluded that users having high absorptive capacity will accept the information in relation to using an ERP system better than users with low absorptive capacity. Further, as users share their knowledge and experiences with others, their personal know-how increases. Thus, ERP systems are more suitable for users with high absorptive capacity. Based on the arguments above, we generated the following hypothesis: 
Hypothesis 3 (H3). Absorptive capacity is positively associated with ERP usage performance.

In addition to the assessment of the independent effects of OCB and absorptive capacity on ERP usage performance, it is critical for this study to evaluate the mediating effect of absorptive capacity in this relationship. The following hypothesis is presented based on the detailed discussion already provided on these variables:

Hypothesis 4 (H4). Absorptive capacity exerts a mediating effect on the relationship between OCB and ERP usage performance.

As previous research has noted that system usage performance is influenced by increasing usage experience [53], ERP usage experience was considered as a control variable in the study. By controlling for differences in users' characteristics related to ERP usage performance, the pure relationships among OCB, absorptive capacity, and ERP usage performance could be further investigated.

\section{Research Methodology}

\subsection{Measurements}

A survey was conducted to validate the research model. The measured items pertaining to OCB and ERP usage performance were selected from previous studies $[10,15,31]$, while the measurement items regarding absorptive capacity consisted of a modified version of existing items to better fit the research context. All of the measurements were scored based on a seven-point Likert scale (1: not at all-7: very much). In addition, two professional IS researchers reviewed the survey to verify the face validity; their inputs were reflected in the final list of items measured as part of the survey. The detailed items of the survey questionnaire are presented in Appendix A.

\subsection{Data Collection}

Data were collected from employees in Korean companies that have been operating ERP systems for several years. To generate the list of target companies, we contacted an IT consulting company that helped its clients implement an ERP system, and asked it to recommend its client companies that have completed ERP implementation projects involving more than two ERP modules. Among 30 companies recommended, 23 expressed willingness to participate. These companies were not limited to small and medium-sized enterprises, i.e., their size was not taken into account. Survey questionnaires were then distributed to the employees of the companies who were expected to use the implemented ERP systems in their tasks. The survey was conducted over a two-week period. Overall, 191 out of the 230 survey questionnaires were returned. Three survey questionnaires were excluded owing to insincerity on the part of a few responses. As a result, 188 survey questionnaires from 23 companies, an average of 8.17 responses per company, were used for the final analysis. The demographics of these samples are described in Table 1.

Table 1. Samples demographics.

\begin{tabular}{cccc}
\hline & Respondents $(\mathbf{n}=\mathbf{~ 1 8 8 )}$ & Frequency & Percentage (\%) \\
\hline \multirow{4}{*}{ Age } & $20 \mathrm{~s}$ & 80 & 42.6 \\
& $30 \mathrm{~s}$ & 82 & 43.6 \\
& $40 \mathrm{~s}$ & 23 & 12.2 \\
& Over 50 & 3 & 1.6 \\
\hline \multirow{2}{*}{ Gender } & Male & 110 & 58.5 \\
& Female & 78 & 41.5 \\
\hline \multirow{3}{*}{ Education } & High school graduate & 16 & 8.5 \\
& University graduate & 151 & 80.3 \\
& Master's degree or higher & 19 & 10.1 \\
& Others & 2 & 1.1 \\
\hline
\end{tabular}


Table 1. Cont.

\begin{tabular}{cccc}
\hline & Respondents (n = 188) & Frequency & Percentage (\%) \\
\hline \multirow{4}{*}{ Position } & Staff & 89 & 47.3 \\
& Assistant manager & 59 & 31.4 \\
& Manager & 26 & 13.8 \\
& Assistant general manager & 10 & 5.3 \\
& General manager or higher & 4 & 2.2 \\
\hline \multirow{5}{*}{ Department } & General management/Planning & 62 & 33.0 \\
& Information systems & 38 & 20.2 \\
& Marketing/Sales & 20 & 10.6 \\
& General affairs/Personnel & 16 & 8.5 \\
& R\&D & 26 & 13.8 \\
& Production/Quality assurance & 17 & 9.1 \\
& Capital/Accounting & 8 & 4.3 \\
& Others & 1 & 0.5 \\
\hline \multirow{4}{*}{ ERP system used } & SAP & 82 & 43.6 \\
& Oracle & 50 & 26.6 \\
& Others & 56 & 29.8 \\
\hline & Marketing & 44 & 23.4 \\
& Financial accounting & 27 & 14.4 \\
& Management accounting & 32 & 17.0 \\
& Customer relationship management & 14 & 7.4 \\
& Purchasing/materials management & 12 & 6.4 \\
Focility/production management & 8 & 4.2 \\
& Personnel & 9 & 4.8 \\
& Supply chain management & 3 & 1.6 \\
& Strategic management & 3 & 1.6 \\
& Others & 36 & 19.1 \\
\hline
\end{tabular}

\section{Analysis and Results}

The partial least squares (PLS) method was used to perform data analyses. PLS is often comparable to covariance-based structural equation modeling (CB-SEM) methods including LISREL and AMOS in simultaneously calculating all the values of both endogenous and exogenous variables in the research model [54]. Although the model fit statistics are not provided in the PLS results, PLS has advantages in modeling formative indicator variables and understanding complicated causal relationships with comparatively fewer requirements regarding data assumptions [55]. PLS was chosen because the proposed research model includes second-order variables with formative first-order indicators (e.g., OCB and absorptive capacity). Following the two-step approach suggested by Anderson and Gerbing (1988) [56], the measurement model was first verified, and then the structural model was analyzed using SmartPLS 3.0. Moreover, common method bias concerns were addressed to check for robustness. Lastly, two separate mediation test methodologies were performed to assess the totality or partiality of the mediation effect.

\subsection{Measurement Model}

Both the exploratory factor analysis (EFA) and the confirmatory factor analysis (CFA) were conducted to verify the reliability and the construct validity of instruments used to measure the variables. Since the model contains two second-order variables, the first-order constructs' factor scores were used to create second-order constructs [55]. Following Thornton et al.'s (2014) [57] suggestion, the validity of second-order variables was examined at the first-order construct level.

In order to evaluate reliability, the values of composite reliability (CR) and Cronbach's alpha were firstly examined. As shown in Table 2, the CR and Cronbach's alpha estimates of all constructs exceeded the recommended threshold value (0.7), confirming reliability [58]. Then the EFA was performed, not only to validate both convergent and discriminant validities, but also to calculate the first-order constructs' factor scores. According to the results of EFA, the measurement model was updated by deleting items that exhibited factor loadings lower than the appropriate level (0.5) [59]. 
CON1, COU3, COU4, TRA3, and TRA4 were the items that were ultimately eliminated. Convergent validity was confirmed using factor loadings and average variance extracted (AVE) values of the first-order constructs by conducting a CFA. As also presented in Table 2, the factor loadings of total measurement items introduced in this study were in excess of 0.5 [60], and the AVE values were also over 0.5 [61]. Henceforth, the measurement model for this study is considered to have convergent validity. The discriminant validity was additionally verified using a method that ascertains whether the square root of the AVE of each construct was higher than the correlation between that construct and the other ones. Table 3 conveys that the square root of the AVE for each construct was, in fact, higher than the correlation between that construct and the other ones, thus proving the discriminant validity of the measurement model.

Table 2. Measurement model.

\begin{tabular}{|c|c|c|c|c|c|c|}
\hline Construct & Dimension & Item & Factor Loading ${ }^{\text {a }}$ & $\mathrm{CR}^{\mathrm{b}}$ & $\operatorname{AVE}^{c}$ & Cronbach $\alpha$ \\
\hline \multirow{17}{*}{$\begin{array}{l}\text { Organizational } \\
\text { citizenship } \\
\text { behavior }\end{array}$} & \multirow{4}{*}{ Altruism } & ALT1 & 0.752 & \multirow{4}{*}{0.910} & \multirow{4}{*}{0.716} & \multirow{4}{*}{0.868} \\
\hline & & ALT2 & 0.885 & & & \\
\hline & & ALT3 & 0.847 & & & \\
\hline & & ALT4 & 0.894 & & & \\
\hline & \multirow{3}{*}{ Conscientiousness } & CON2 & 0.540 & \multirow{3}{*}{0.830} & \multirow{3}{*}{0.630} & \multirow{3}{*}{0.749} \\
\hline & & CON3 & 0.863 & & & \\
\hline & & CON4 & 0.925 & & & \\
\hline & \multirow{2}{*}{ Courtesy } & COU1 & 0.862 & \multirow{2}{*}{0.882} & \multirow{2}{*}{0.788} & \multirow{2}{*}{0.735} \\
\hline & & COU2 & 0.913 & & & \\
\hline & \multirow{4}{*}{ Sportsmanship } & SPO1 & 0.790 & \multirow{4}{*}{0.878} & \multirow{4}{*}{0.644} & \multirow{4}{*}{0.815} \\
\hline & & $\mathrm{SPO} 2$ & 0.835 & & & \\
\hline & & SPO3 & 0.856 & & & \\
\hline & & SPO4 & 0.723 & & & \\
\hline & \multirow{4}{*}{ Civic virtue } & CIV1 & 0.807 & \multirow{4}{*}{0.895} & \multirow{4}{*}{0.681} & \multirow{4}{*}{0.844} \\
\hline & & CIV2 & 0.862 & & & \\
\hline & & CIV3 & 0.840 & & & \\
\hline & & CIV4 & 0.790 & & & \\
\hline \multirow{15}{*}{$\begin{array}{l}\text { Absorptive } \\
\text { capacity d }\end{array}$} & \multirow{4}{*}{ Acquisition } & ACQ1 & 0.776 & \multirow{4}{*}{0.869} & \multirow{4}{*}{0.625} & \multirow{4}{*}{0.804} \\
\hline & & ACQ2 & 0.842 & & & \\
\hline & & ACQ3 & 0.790 & & & \\
\hline & & ACQ4 & 0.746 & & & \\
\hline & & ASS1 & 0.879 & & & \\
\hline & & ASS2 & 0.902 & & & \\
\hline & Assimilation & ASS3 & 0.875 & 0.950 & 0.790 & 0.934 \\
\hline & & ASS4 & 0.880 & & & \\
\hline & & ASS5 & 0.907 & & & \\
\hline & Transformation & TRA1 & 0.935 & & 0883 & 0868 \\
\hline & Iransformation & TRA2 & 0.944 & 0.938 & 0.883 & 0.868 \\
\hline & & EXP1 & 0.875 & & & \\
\hline & Exploitation & EXP2 & 0.895 & 0933 & 0778 & 0905 \\
\hline & & EXP3 & 0.891 & 0.933 & $0.7 / 8$ & 0.905 \\
\hline & & EXP4 & 0.866 & & & \\
\hline & & EUP1 & 0.941 & & & \\
\hline & & EUP2 & 0.965 & & & \\
\hline performance & - & EUP3 & 0.951 & 0.973 & 0.880 & 0.966 \\
\hline & & EUP4 & 0.918 & & & \\
\hline & & EUP5 & 0.913 & & & \\
\hline $\begin{array}{l}\text { ERP usage } \\
\text { experience }\end{array}$ & - & EUE1 & 1.000 & 1.000 & 1.000 & 1.000 \\
\hline
\end{tabular}


Table 3. Construct correlations and discriminant validity.

\begin{tabular}{|c|c|c|c|c|c|c|c|c|c|c|c|}
\hline Construct & ALT & CON & COU & SPO & CIV & $\mathrm{ACQ}$ & ASS & TRA & EXP & EUP & EUE \\
\hline ALT & 0.846 & & & & & & & & & & \\
\hline $\mathrm{CON}$ & 0.446 & 0.794 & & & & & & & & & \\
\hline COU & 0.465 & 0.483 & 0.888 & & & & & & & & \\
\hline SPO & 0.515 & 0.413 & 0.467 & 0.803 & & & & & & & \\
\hline CIV & 0.428 & 0.486 & 0.406 & 0.513 & 0.825 & & & & & & \\
\hline $\mathrm{ACQ}$ & 0.143 & 0.105 & 0.157 & 0.156 & 0.356 & 0.791 & & & & & \\
\hline ASS & 0.260 & 0.246 & 0.297 & 0.247 & 0.333 & 0.585 & 0.889 & & & & \\
\hline TRA & 0.254 & 0.205 & 0.216 & 0.238 & 0.353 & 0.439 & 0.613 & 0.940 & & & \\
\hline EXP & 0.136 & 0.145 & 0.168 & 0.203 & 0.306 & 0.522 & 0.664 & 0.632 & 0.882 & & \\
\hline EUP & 0.154 & 0.231 & 0.274 & 0.221 & 0.329 & 0.348 & 0.473 & 0.442 & 0.605 & 0.938 & \\
\hline EUE & 0.141 & 0.135 & 0.000 & 0.051 & 0.139 & 0.063 & 0.132 & 0.215 & 0.045 & 0.186 & 1.000 \\
\hline Mean & 5.299 & 5.096 & 5.641 & 4.926 & 4.854 & 4.065 & 4.306 & 4.468 & 4.150 & 5.035 & 66.03 \\
\hline S.D. ${ }^{a}$ & 1.044 & 1.093 & 0.954 & 0.981 & 1.032 & 1.190 & 1.160 & 1.214 & 1.218 & 1.267 & 67.89 \\
\hline
\end{tabular}

a Standard deviation; Note: The diagonals in italic bold shows the square roots of AVEs, while off diagonal entries are the correlation coefficients among first-order constructs

\subsection{Stuctural Model}

The structure model was evaluated using the variances of the explained endogenous variables $\left(R^{2}\right)$ and the values of the path coefficients $(\beta)$ that passed the significance level test. OCB, which consists of the first-order factors of altruism, conscientiousness, courtesy, sportsmanship, and civic virtue, as well as absorptive capacity, which consists of the first-order factors of acquisition, assimilation, transformation, and exploitation, were expressed as second-order variables. Second-order variables, such as OCB and absorptive capacity, were then indirectly measured through the lower-order formative factors. A bootstrapping resampling method (5000 repetitions) was performed. As shown in Figure 2, which illustrates the paths' coefficients and $t$-statistic values for the structural models, the three posited hypotheses ( $\mathrm{H} 1, \mathrm{H} 2$, and $\mathrm{H} 3$ ) were supported. OCB is positively associated with both ERP usage performance and absorptive capacity $(\beta=0.155, p<0.05$ and $\beta=0.394, p<0.001$, respectively), thus supporting Hypotheses 1 and 2. Absorptive capacity is also significantly associated with ERP usage performance $(\beta=0.529, p<0.001)$, supporting Hypothesis 3 . A control variable, ERP usage experience, also had a significant relationship with ERP usage performance $(\beta=0.109, p<0.05)$. OCB, absorptive capacity, and the control variable explained the variance of ERP usage performance at approximately $40 \%\left(R^{2}=0.397\right)$. In addition, the variance of absorptive capacity was explained by OCB at approximately $16 \%\left(\mathrm{R}^{2}=0.156\right)$.

As all data were perceptually collected in a cross-sectional single setting, there is a potential threat of common method bias. Thus, two statistical analyses were conducted to address this issue. First, Harman's one-factor test was conducted, following Podsakoff and Organ (1986) [62], in which all items in principal components of the EFA (without rotation) were included. According to this test, the threat of common method bias is high if a single factor emerges or if one latent factor accounts for a majority of the covariance among the manifest variables. The results of the EFA indicate that nine factors with eigenvalues greater than one (combined account for 73.83\%) emerged, and no single factor explained the majority of the covariance (a factor with the greatest eigenvalue explained $31.55 \%$ ). Second, following the recommendation of Liang et al. (2007) [63], the latent common methods technique was conducted. More specifically, a common method factor whose indicators include all 38 items used in the study was added to the structural model. The results in Appendix B show that all the substantive factor loadings remain significant despite the inclusion of the common method factor, whereas most method factor loadings are not significant. Moreover, the average substantive variance of the item explained by principal constructs $(75.2 \%)$ is substantially greater than the average variance explained by the common method factor $(0.3 \%)$. Therefore, these tests combined indicate that common method bias is unlikely to be a major threat to the study. 


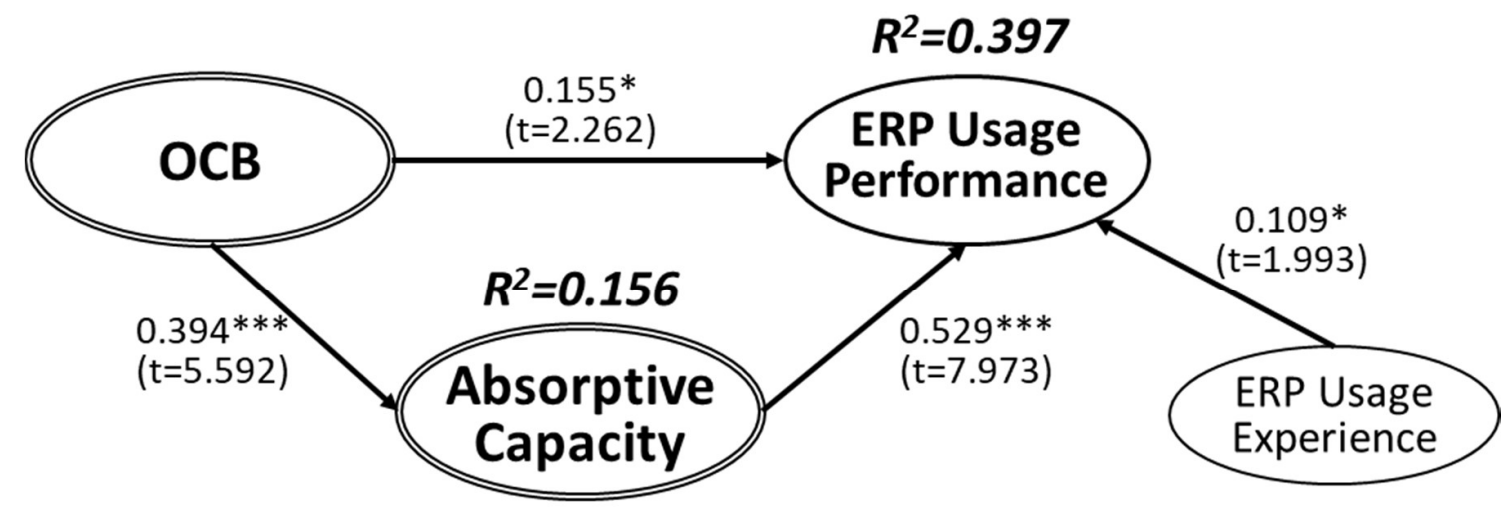

$*: p<0.05 ; * * *: p<0.001$

(a) The main relationships among $\mathrm{OCB}$, absorptive capacity, and ERP usage performance, including a control variable (ERP usage experience).

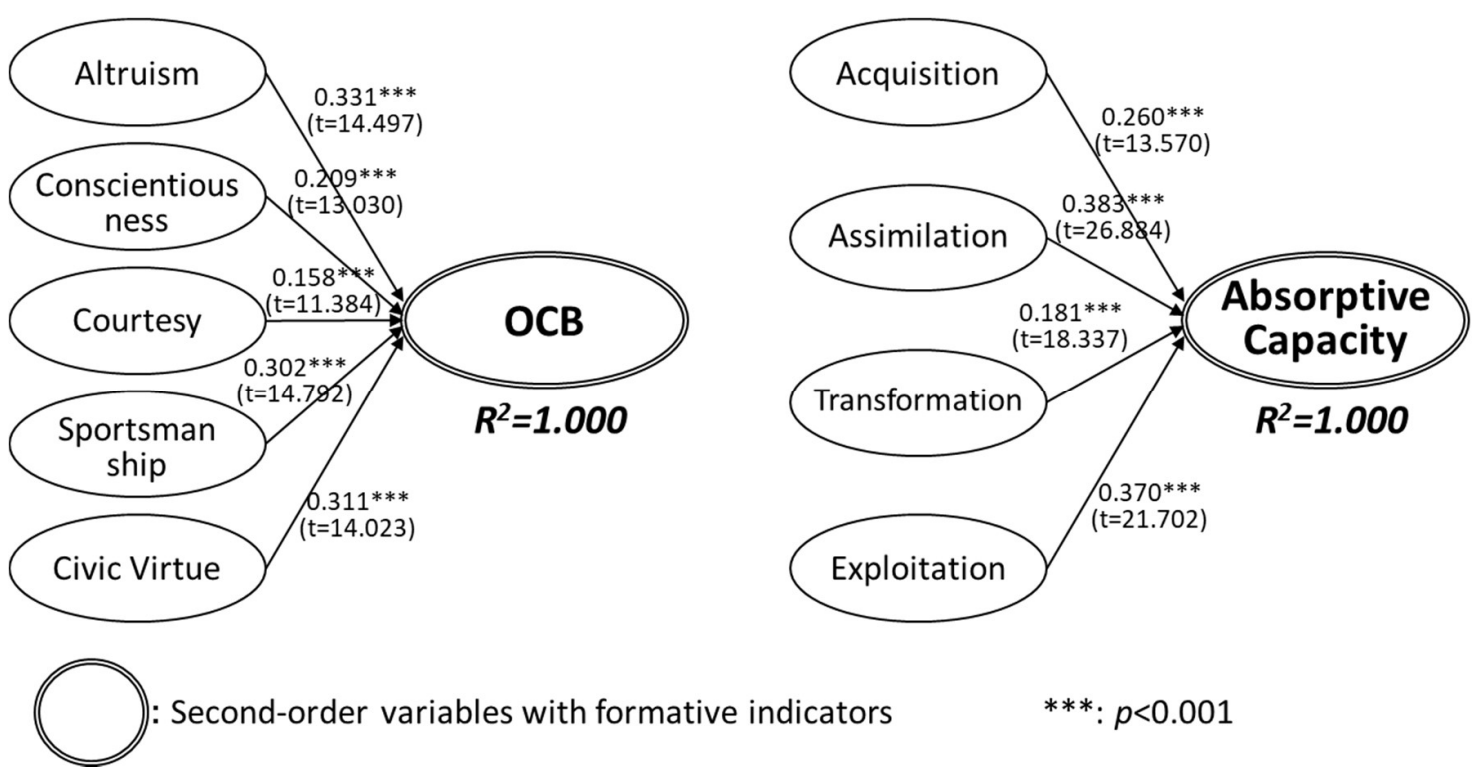

(b) The relationships between second-order variables and formative first-order factors.

Figure 2. The result of the structural model.

\subsection{Mediation Tests}

The mediating role of absorptive capacity was examined in two different ways, in accordance with previous research [64,65]. For the first test, Baron and Kenny's (1986) [64] testing was implemented with the following regression models in sequence:

$$
\begin{gathered}
\mathrm{AC}=\beta_{0}+\beta_{1} \times \mathrm{OCB}+\varepsilon \\
\mathrm{EUP}=\beta_{0}+\beta_{1} \times \mathrm{OCB}+\varepsilon \\
\mathrm{EUP}=\beta_{0}+\beta_{1} \times \mathrm{OCB}+\beta_{2} \times \mathrm{AC}+\varepsilon
\end{gathered}
$$

where AC: absorptive capacity, OCB: organizational citizenship behavior, EUP: ERP usage performance.

The results of the regression analysis are organized in Table 4 . All beta coefficients in the three equations are significant at the 0.001 levels, except for the relationship between OCB and EUP in 
Equation (3), which is significant at the 0.05 level. Also, the beta coefficient of OCB in Equation (2) (i.e., 0.310) is larger than the value in Equation (3) (i.e., 0.142), thus supporting the partial mediation effect of absorptive capacity on the relationship between OCB and ERP usage performance.

Table 4. The mediation effect test: Baron and Kenny's testing.

\begin{tabular}{cccccc}
\hline Regression Equation & Dependent Variable & Adjusted $\mathbf{R}^{\mathbf{2}}$ & F-Value & $\boldsymbol{\beta}_{\mathbf{i}}$ & $\boldsymbol{t}$-Value \\
\hline $\begin{array}{c}\text { Equation (1) } \\
\text { OCB }\end{array}$ & AC & 0.108 & $23.618^{* * *}$ & & \\
\hline $\begin{array}{c}\text { Equation (2) } \\
\text { OCB }\end{array}$ & EUP & 0.091 & $19.775^{* * *}$ & & \\
\hline Equation (3) & & & & 0.336 & $4.860^{* * *}$ \\
OCB & EUP & 0.311 & $43.136^{* * *}$ & & \\
AC & & & & 0.142 & $2.205^{* * *}$ \\
\hline
\end{tabular}

${ }^{*}$ Significant at the $p<0.05$ level (two-tailed); ${ }^{* * *}$ significant at the $p<0.001$ level (two-tailed).

In executing the second test, Sobel's (1982) [65] individual mediated paths analysis was applied to the research model. The path coefficients and standard errors regarding all involved independent, mediating, and dependent variables are utilized to compute the Z-value of the mediating path between independent and dependent variables [66]. The partial mediating effect of absorptive capacity on the relationship between OCB and ERP usage performance is evident by a positive path magnitude value and a significant Z-value, as shown in Table 5. Based on the results of these two tests, it is concluded that absorptive capacity has a partial mediating role in the relationship between OCB and ERP usage performance, thereby supporting Hypothesis 4.

Table 5. The mediation effect test: Sobel's individual mediated paths model.

\begin{tabular}{cccc}
\hline Direct Effect & Mediated Path & Z-Value & $p$-Value \\
\hline $\mathrm{OCB} \rightarrow \mathrm{EUP}$ & $\mathrm{OCB} \rightarrow \mathrm{AC} \rightarrow$ EUP & $4.127^{* * *}$ & 0.00003675 \\
\hline \multicolumn{4}{c}{$\mathrm{n}=188^{* * *}$ significant at the $p<0.001$ level (two-tailed). }
\end{tabular}

\section{Discussion and Conclusions}

\subsection{Discussion of Findings}

This study focuses on the usage performance of ERP systems by the members of an organization who play an important role in the successful implementation of such systems. The core concept of the study involves an empirical analysis of how $O C B$, rooted in social exchange theory, influences ERP usage performance through the mediation of individual absorptive capacity. As a result of the analysis, the following conclusions were reached. First, OCB significantly influences absorptive capacity. This result is consistent with the findings of previous studies [47,48], which have indicated that cooperation, sharing, and communication between members of an organization play important functions in knowledge creation, that consists of acquisition, assimilation, transformation, and exploitation. Thus, $\mathrm{OCB}$, which includes helping others, refraining from airing out complaints or grievances, caring for others, abiding by the rules and regulations of the company, and keeping abreast of company policies, positively influences absorptive capacity. In addition, the expected compensation stemming from social exchange relationships becomes a motivational factor for knowledge exchange, and furthermore, positively influences knowledge sharing [45].

Second, the results showed that the absorptive capacity of members in an organization significantly influences the usage performance of ERP systems. Prior research [31] has demonstrated that ERP systems could initiate changes in work processes and in the dissemination of advanced knowledge; hence, it is important to strengthen the absorptive capacity of individuals in order to improve the 
usage performance of ERP systems. Nelson and Cooprider's (1996) [67] study also asserted that knowledge sharing among IS teams and team members positively influences the team performance. Therefore, the behaviors based on individuals' improved absorptive capacity, such as sharing ERP system-related knowledge with others, the development of know-how through knowledge sharing, and the exploitation of such know-how during the execution of one's job tasks, can positively influence the usage performance of ERP systems by inducing ERP systems usage in a useful and helpful manner.

Third, social exchange relationships positively influence users' perceptions of an ERP system's usefulness (i.e., conceptualized as ERP usage performance in this study) [68]. In addition, social exchange relationships, in their capacity as motivational factors, positively influence knowledge sharing [45]. Regarding knowledge provision, intrinsic benefits were more influential than the extrinsic ones [44]. Existing studies $[36,38,39,46-50]$ have advanced the notion that the behaviors of members in an organization (i.e., OCB in this study), rooted in social exchange relationships, independently influence both the usage performance of IS (i.e., ERP usage performance in this study) and knowledge sharing ability (i.e., absorptive capacity in this study). This research revealed that, in keeping with the findings of these previous studies, OCB and absorptive capacity independently influence the usage performance of ERP systems. Simultaneous consideration of these three variables revealed that both OCB and absorptive capacity significantly influence the usage performance of ERP systems. In other words, absorptive capacity was found to have a partial mediation effect on the relationship between OCB and ERP usage performance. Knowledge-based theory [69] contends that an enterprise's raison d'être lies in its knowledge integration capability under which knowledge is shared and exploited, not only to facilitate the application of existing knowledge to job tasks, but also to create new knowledge. Therefore, it is understandable that the individual level of absorptive capacity, which plays an important role in the sharing and exploitation of knowledge, will also play a partial, yet significant, role during individual and organizational assimilation, through which new innovations, such as the deployment of ERP systems, are adopted. For this reason, the direct influence of an additional factor (i.e., OCB introduced in this study) will inevitably diminish. The partial mediation effect of absorptive capacity suggests that the direct or indirect effect of OCB on the usage performance of ERP systems could be valuable, depending on different circumstances. When mediated by absorptive capacity, frequent interactions with one's colleagues, based on voluntary and altruistic behaviors and associated with OCB, will facilitate the transfer of personal learning, thus positively influencing the usage performance of ERP systems.

\subsection{Theoretical Implications}

This study raises several theoretical implications for future researchers. First, as Shang and Hsu (2007) [1] evoked, although the successful or failed implementation of ERP systems is premised on factors such as user training, communications, documentation, change management, process optimization, integration/expansion, informationalization, and the activation of system use, these factors are closely related to absorptive capacity. The lack of knowledge sharing and transfer associated with absorptive capacity is the overarching cause of decreased usage performance of ERP systems by members of an organization $[5,6,67]$. A heavy emphasis is placed on the importance of the abilities of individuals to acquire, transform, and exploit knowledge in IT usage performance. However, a few studies to date have been conducted on the topic of absorptive capacity and IT usage performance [31,40-43,52]. In particular, there have been very few studies in which OCB has been positioned as an antecedent variable to absorptive capacity. Amidst such circumstances, this study established a theoretical model proving that absorptive capacity is an important variable influencing ERP usage performance.

Second, OCB was proposed as an antecedent factor of absorptive capacity, which is closely related to knowledge transfer and sharing. A study on the link between social exchange relationships and knowledge sharing [46] manifested the benefits expected from the transformation of knowledge into intrinsic and extrinsic compensation via the sharing and transferring processes. The latter study by Lin (2007) [70] advanced the notion that intrinsic compensation has a stronger influence on the provision and sharing of knowledge than extrinsic compensation. OCB is closely related to intrinsic compensation 
from a theoretical standpoint. A few studies on OCB have been conducted with respect to changes in management [36] and the successful management of ERP systems [39] in IS. These studies proved that OCB influences the usage performance of ERP systems through absorptive capacity, evidencing the important role of OCB in IS.

Third, this study showed that absorptive capacity partially mediated the relationship between OCB and ERP usage performance. Social exchange relationships and the intrinsic benefits of individuals, such as OCB, are closely related to their performance $[44,45,68]$. While these studies assume that knowledge sharing and the transfer mechanism are embedded in the influencing process, this research argues that the absorptive capacity of individuals intervenes explicitly between OCB (i.e., representing social exchange relationships and intrinsic motivation) and IT usage performance. This argument may provide some theoretical insights for future researchers who may be interested in the role of absorptive capacity from a social exchange perspective. In addition, based on the empirical results, this study presents a theoretical basis upon which future studies can explore the influential relationship that may exist between the various sub-dimensions of OCB and absorptive capacity to better understand the specific roles of absorptive capacity as a full mediator.

\subsection{Practical Implications}

A lot of companies facing a severely competitive environment have implemented the ERP system as a strategic means. But, only a few cases of such ERP systems have been implemented. Failure in the successful management of such systems can lead to a considerable loss of investment, associated with low business efficiency. In order to avoid damage to businesses, we examined the absorptive capacity and OCB as the factors influencing the successful management of ERP systems. This study has two major practical implications.

First, this study proved that individual absorptive capacity was an important variable in ensuring the successful and productive use of ERP systems. As individuals have different capacities to acquire, share, and exploit knowledge, the use of such knowledge will differ, despite the fact that users may have received the same level of education amidst an identical environment. Therefore, efforts should be made to emphasize the simultaneous enhancement of individual absorptive capacity over unilateral education and training in order to use ERP systems effectively. In doing so, enterprises should pay more attention toward creating explicit knowledge from implicit knowledge to facilitate users' ability to obtain information and knowledge about ERP systems, and furthermore, to create an environment in which information and knowledge can be easily exploited. In addition, it is necessary to implement not only basic ERP system education but also various educational programs whose contents can be exploited during the execution of job tasks. It is also essential that the motivation to learn about ERP systems is enhanced by awarding prizes to those employees who exhibit excellent results. Furthermore, it is necessary to create an environment of integrating and combining the knowledge (i.e., sharing know-how) of pertinent parties on ERP systems usage via regular meetings and training sessions.

Second, this study confirmed the empirical significance of OCB on absorptive capacity. Since all behaviors of members in an organization cannot be officially defined by the roles associated with their job tasks, the creation and exploitation of knowledge require the promotion of non-compensational and voluntary behaviors outside of the organization's official policies. Enterprises should make efforts to establish a corporate culture that encourages trust and camaraderie among members. Moreover, various channels and programs should be put in place to promote the development of friendly relationships among members of an organization.

Third, this study adopted the 'knowledge management' perspective when analyzing ERP performance. Thus, it proposed absorptive capacity and OCB as the main factors that lead to the high performance of ERP users and empirically proved that they play a significant role. This implies that effective knowledge management is very important for successful ERP implementation. Therefore, companies preparing for ERP adoption should make efforts to build an effective knowledge management system to facilitate knowledge sharing and knowledge transfer among members of the organization. 
Appropriate organizational culture and policy for knowledge management will also be required for the successful implementation of ERP systems.

\subsection{Limitations and Future Research Directions}

First, this study limited itself to the analysis of general relationships among OCB, absorptive capacity, and the usage performance of ERP systems. However, no analysis was conducted on the relationship between the subordinate concepts of OCB and the subordinate concepts of absorptive capacity, or on that between the subordinate concepts of absorptive capacity and the usage performance of ERP systems. Considering the results of our study, it is necessary to conduct future studies on the relationship between the subordinate concepts of the two independent variables and on the influence of the subordinate concepts of absorptive capacity on the usage performance of ERP systems. Such studies will inevitably provide more organized management guidance for better management of ERP systems.

Second, the number of manufacturing/distribution/service industry enterprises that participated in the survey was high, compared to other industries. Hence, caution should be exercised when applying the findings to other industries.

Third, our study did not address the possible temporal effects, owing to the service duration of the ERP systems. Several researchers and actual users acknowledged the low performance of the ERP systems during the early stages of their implementation [71]. Thus, the usefulness of ERP systems could have been improperly measured for those who took part in this survey while the implementation of ERP systems was still in its early stages.

Fourth, this study only considered OCB as an antecedent variable of absorptive capacity. It did not consider extrinsic factors, such as corporate incentive policies, alongside intrinsic motivation factors, such as non-compensational and voluntary behaviors. Hence, more complete models that include other critical variables should be studied in the future.

Author Contributions: Conceptualization, K.-Y.K., S.-B.Y. and H.A.; methodology, K.-Y.K.; validation, K.-Y.K.; formal analysis, K.-Y.K. and S.-B.Y.; investigation, K.-Y.K.; resources, K.-Y.K.; data curation, K.-Y.K.; writing-original draft preparation, K.-Y.K.; writing-review and editing, K.-Y.K., S.-B.Y. and H.A.; visualization, S.-B.Y. and H.A.; supervision, K.-Y.K.; project administration, K.-Y.K.; funding acquisition, K.-Y.K. All authors have read and agreed to the published version of the manuscript.

Funding: This work was supported by the Ministry of Education of the Republic of Korea and the National Research Foundation of Korea (NRF-2018S1A3A2075114).

Conflicts of Interest: The authors declare no conflict of interest. The funders had no role in the design of the study; in the collection, analyses, or interpretation of data; in the writing of the manuscript, or in the decision to publish the results.

\section{Appendix A}

Table A1. Measurement Items.

\begin{tabular}{|c|c|c|c|c|}
\hline & iable & Item & Measure (7-Point Likert Scale) & Ref. \\
\hline \multirow{8}{*}{$\begin{array}{l}\text { Organizational } \\
\text { citizenship } \\
\text { behavior }\end{array}$} & \multirow{4}{*}{ Altruism } & ALT1 & I am willing to carry out the job duties of an absent co-worker. & \multirow{8}{*}{10,15} \\
\hline & & ALT2 & I gladly help out a co-worker who has too much work to do. & \\
\hline & & ALT3 & $\begin{array}{l}\text { Though I am not directly responsible for them, I tend to help } \\
\text { new employees adjust to the company. }\end{array}$ & \\
\hline & & ALT4 & I generally help my co-workers. & \\
\hline & \multirow{4}{*}{ Conscientiousness } & CON1 & I think that it is important to go to work every day. [deleted] & \\
\hline & & CON2 & $\begin{array}{l}\text { I do not take any breaks during work other than those given } \\
\text { by the company. }\end{array}$ & \\
\hline & & CON3 & $\begin{array}{l}\text { I abide by the official rules and regulations of the company } \\
\text { even though there is nobody watching me. }\end{array}$ & \\
\hline & & CON4 & $\begin{array}{l}\text { I believe that the amount of work I do is commensurate to the } \\
\text { salary I earn. }\end{array}$ & \\
\hline
\end{tabular}


Table A1. Cont.

\begin{tabular}{|c|c|c|c|c|}
\hline & Variable & Item & Measure (7-Point Likert Scale) & Ref. \\
\hline & \multirow{4}{*}{ Courtesy } & COU1 & $\begin{array}{l}\text { I avoid any matters that may cause a problem for my } \\
\text { co-workers. }\end{array}$ & \\
\hline & & COU2 & $\begin{array}{l}\text { I think about how my behavior will influence other } \\
\text { co-workers. }\end{array}$ & \\
\hline & & COU3 & I do not speak ill of my company or co-workers. [deleted] & \\
\hline & & COU4 & $\begin{array}{l}\text { I do not violate or impinge on the rights of other co-workers. } \\
\text { [deleted] }\end{array}$ & \\
\hline & \multirow{4}{*}{ Sportsmanship } & SPO1 & $\begin{array}{c}\text { I do not create waves with regard to any matters that may } \\
\text { arise within the company. }\end{array}$ & \\
\hline & & $\mathrm{SPO} 2$ & $\begin{array}{l}\text { I focus on the positive aspects of any matter that emerges } \\
\text { rather than the negative ones. }\end{array}$ & \\
\hline & & SPO3 & $\begin{array}{l}\text { I do not spend much time pointing out the weak points of the } \\
\text { company. }\end{array}$ & \\
\hline & & $\mathrm{SPO} 4$ & I do not complain about small problems within the company. & \\
\hline & \multirow{4}{*}{ Civic virtue } & CIV1 & $\begin{array}{l}\text { I voluntarily participate in the meetings that I regard as being } \\
\text { important. }\end{array}$ & \\
\hline & & CIV2 & $\begin{array}{l}\text { Even though it is not part of my work duties, I voluntarily } \\
\text { participate in any matters that can improve the image of the } \\
\text { company. }\end{array}$ & \\
\hline & & CIV3 & $\begin{array}{l}\text { I abide by the policies and innovative measures put in place } \\
\text { by the company. }\end{array}$ & \\
\hline & & CIV4 & $\begin{array}{l}\text { I voice my opinions whenever I think that these may be } \\
\text { helpful in the development of company. }\end{array}$ & \\
\hline \multirow{4}{*}{\multicolumn{2}{|c|}{ Acquisition }} & ACQ1 & $\begin{array}{l}\text { I understand the information introduced by the company as } \\
\text { part of its efforts to achieve its goals. }\end{array}$ & \\
\hline & & ACQ2 & $\begin{array}{c}\text { I obtain the information regarding the usage and management } \\
\text { of ERP systems through official education or partner } \\
\text { organizations. }\end{array}$ & {$[25,72]$} \\
\hline & & ACQ3 & I visit other departments and branch offices on a regular basis. & \\
\hline & & ACQ4 & $\begin{array}{l}\text { I frequently interact with co-workers and the information } \\
\text { systems department to obtain information about the usage of } \\
\text { the new ERP system. }\end{array}$ & \\
\hline \multirow{13}{*}{$\begin{array}{l}\text { Absorptive } \\
\text { capacity }\end{array}$} & \multirow{5}{*}{ Assimilation } & ASS1 & I understand the skills needed to use ERP systems. & \multirow{5}{*}[29,72]{} \\
\hline & & ASS2 & $\begin{array}{l}\text { I possess the technological/managerial abilities needed to } \\
\text { promptly understand the training and learning programs } \\
\text { associated with ERP systems. }\end{array}$ & \\
\hline & & ASS3 & I possess the latest information on how to use ERP systems. & \\
\hline & & ASS4 & $\begin{array}{l}\text { My co-workers and I employ common tools to understand the } \\
\text { usage of ERP systems. }\end{array}$ & \\
\hline & & ASS5 & $\begin{array}{l}\text { I am able to promptly analyze and interpret any requirements } \\
\text { or changes associated with the performance of my job tasks. }\end{array}$ & \\
\hline & \multirow{4}{*}{ Transformation } & TRA1 & $\begin{array}{l}\text { I store or record newly acquired knowledge in order to be able } \\
\text { to refer to it in the future. }\end{array}$ & \multirow{4}{*}{ [72] } \\
\hline & & TRA2 & $\begin{array}{l}\text { I perceive the usefulness of new external knowledge when it } \\
\text { comes to the exploitation of knowledge. }\end{array}$ & \\
\hline & & TRA3 & I am able to easily share practical experiences. [deleted] & \\
\hline & & TRA4 & $\begin{array}{l}\text { I regularly hold meetings with co-workers in order to discuss } \\
\text { and exchange opinions. [deleted] }\end{array}$ & \\
\hline & \multirow{4}{*}{ Exploitation } & EXP1 & $\begin{array}{l}\text { I am able to exploit the knowledge obtained from ERP } \\
\text { systems and use it to perform other job duties. }\end{array}$ & \multirow{4}{*}[25,29,72]{} \\
\hline & & EXP2 & $\begin{array}{l}\text { I am able to apply the information obtained from advanced } \\
\text { ERP processes to my own job duties. }\end{array}$ & \\
\hline & & EXP3 & I use ERP systems to share knowledge. & \\
\hline & & EXP4 & $\begin{array}{l}\text { I am able to easily apply knowledge obtained from other } \\
\text { departments to my job duties. }\end{array}$ & \\
\hline
\end{tabular}


Table A1. Cont.

\begin{tabular}{|c|c|c|c|c|}
\hline Variable & & Item & Measure (7-Point Likert Scale) & Ref. \\
\hline \multirow{5}{*}{$\begin{array}{l}\text { ERP usage } \\
\text { performance }\end{array}$} & \multirow{5}{*}{ - } & EUP1 & The use of ERP systems has increased job performance usefulness. & \multirow{5}{*}{ [31] } \\
\hline & & EUP2 & $\begin{array}{l}\text { The use of ERP systems has increased job performance } \\
\text { productivity. }\end{array}$ & \\
\hline & & EUP3 & The use of ERP systems has enhanced job performance efficiency. & \\
\hline & & EUP4 & $\begin{array}{l}\text { The use of ERP systems has made it possible to carry out job } \\
\text { duties more promptly. }\end{array}$ & \\
\hline & & EUP5 & The use of ERP systems has resulted in improved job performance. & \\
\hline $\begin{array}{l}\text { ERP usage } \\
\text { experience }\end{array}$ & - & EUE1 & $\begin{array}{c}\text { I have been using this ERP system since (year) and (month). [The } \\
\text { total number of months using the ERP system]. }\end{array}$ & \\
\hline
\end{tabular}

\section{Appendix B}

Table A2. The Results of Common Method Bias Test.

\begin{tabular}{|c|c|c|c|c|c|}
\hline Variable & Item & $\begin{array}{l}\text { Substantive Factor } \\
\text { Loading (R1) }\end{array}$ & $\mathbf{R} \mathbf{1}^{2}$ & $\begin{array}{l}\text { Common Method } \\
\text { Factor Loading (R2) }\end{array}$ & $\mathrm{R} 2^{2}$ \\
\hline \multirow{4}{*}{ Altruism } & ALT1 & $0.805^{* *}$ & 0.648 & -0.061 & 0.004 \\
\hline & ALT2 & $0.898^{* *}$ & 0.806 & -0.014 & 0.000 \\
\hline & ALT3 & $0.844^{* *}$ & 0.712 & -0.004 & 0.000 \\
\hline & ALT4 & $0.841^{* *}$ & 0.707 & 0.070 & 0.005 \\
\hline \multirow{3}{*}{ Conscientiousness } & CON2 & $0.802^{* *}$ & 0.643 & $-0.151 * *$ & 0.023 \\
\hline & CON3 & $0.850 * *$ & 0.723 & 0.029 & 0.001 \\
\hline & CON4 & $0.804^{* *}$ & 0.646 & 0.095 & 0.009 \\
\hline \multirow{2}{*}{ Courtesy } & COU1 & $0.910 * *$ & 0.828 & -0.051 & 0.003 \\
\hline & COU2 & $0.868^{* *}$ & 0.753 & 0.049 & 0.002 \\
\hline \multirow{4}{*}{ Sportsmanship } & SPO1 & $0.800^{* *}$ & 0.640 & -0.018 & 0.000 \\
\hline & $\mathrm{SPO} 2$ & $0.810^{* *}$ & 0.656 & 0.025 & 0.001 \\
\hline & $\mathrm{SPO} 3$ & $0.863^{* *}$ & 0.745 & -0.018 & 0.000 \\
\hline & $\mathrm{SPO} 4$ & $0.733^{* *}$ & 0.537 & 0.012 & 0.000 \\
\hline \multirow{4}{*}{ Civic Virtue } & CIV1 & $0.761 * *$ & 0.579 & 0.047 & 0.002 \\
\hline & CIV2 & $0.867^{* *}$ & 0.752 & -0.011 & 0.000 \\
\hline & CIV3 & $0.842 * *$ & 0.709 & 0.012 & 0.000 \\
\hline & CIV4 & $0.832 * *$ & 0.692 & -0.049 & 0.002 \\
\hline \multirow{4}{*}{ Acquisition } & ACQ1 & $0.759 * *$ & 0.576 & 0.027 & 0.001 \\
\hline & ACQ2 & $0.749 * *$ & 0.561 & 0.088 & 0.008 \\
\hline & ACQ3 & $0.772 * *$ & 0.596 & 0.033 & 0.001 \\
\hline & ACQ4 & $0.897^{* *}$ & 0.805 & $-0.153 *$ & 0.023 \\
\hline \multirow{5}{*}{ Assimilation } & ASS1 & $0.903^{* *}$ & 0.815 & -0.033 & 0.001 \\
\hline & ASS2 & $0.895^{* *}$ & 0.801 & 0.005 & 0.000 \\
\hline & ASS3 & $0.882 * *$ & 0.778 & -0.005 & 0.000 \\
\hline & ASS4 & $0.848^{* *}$ & 0.719 & 0.042 & 0.002 \\
\hline & ASS5 & $0.916^{* *}$ & 0.839 & -0.009 & 0.000 \\
\hline \multirow{2}{*}{ Transformation } & TRA1 & $0.995^{* *}$ & 0.990 & $-0.079 *$ & 0.006 \\
\hline & TRA2 & $0.885^{* *}$ & 0.783 & $0.078 *$ & 0.006 \\
\hline \multirow{4}{*}{ Exploitation } & EXP1 & $0.868^{* *}$ & 0.753 & 0.005 & 0.000 \\
\hline & EXP2 & $0.867^{* *}$ & 0.752 & 0.027 & 0.001 \\
\hline & EXP3 & $0.947^{* *}$ & 0.897 & -0.067 & 0.004 \\
\hline & EXP4 & $0.845^{* *}$ & 0.714 & 0.036 & 0.001 \\
\hline \multirow{5}{*}{$\begin{array}{l}\text { ERP Usage } \\
\text { Performance }\end{array}$} & EUP1 & $0.904^{* *}$ & 0.817 & 0.049 & 0.002 \\
\hline & EUP2 & $0.953 * *$ & 0.908 & 0.015 & 0.000 \\
\hline & EUP3 & $0.972 * *$ & 0.945 & -0.028 & 0.001 \\
\hline & EUP4 & $0.989 * *$ & 0.978 & $-0.093 *$ & 0.009 \\
\hline & EUP5 & $0.872 * *$ & 0.760 & 0.056 & 0.003 \\
\hline ERP Usage Experience & EUE1 & 1.000 & 1.000 & 0.000 & 0.000 \\
\hline Average & & 0.864 & 0.752 & -0.001 & 0.003 \\
\hline
\end{tabular}

* Significant at the $p<0.05$ level (two-tailed); ${ }^{* *}$ significant at the $p<0.01$ level (two-tailed). 


\section{References}

1. Shang, S.; Hsu, C. Reap from ERP systems: The management of absorptive capacity in post-ERP implementation. In Proceedings of the AMCIS 2007 Proceedings, Keystone, CO, USA, 9-12 August 2007; p. 87.

2. Huang, S.Y.; Chiu, A.A.; Chao, P.C.; Arniati, A. Critical Success Factors in Implementing Enterprise Resource Planning Systems for Sustainable Corporations. Sustainability 2019, 11, 6785. [CrossRef]

3. Warren, A.M. Increasing the value of research: A comparison of the literature on critical success factors for projects, IT projects and enterprise resource planning projects. Systems 2016, 4, 33. [CrossRef]

4. Davison, R.M.; Ou, C.X.; Ng, E. Inadequate information systems and organizational citizenship behavior. Inf. Manag. 2019, 103240. [CrossRef]

5. Davenport, T.H. Putting the enterprise into the enterprise system. Harv. Bus. Rev. 1998, 76, 121-131.

6. Soh, C.; Kien, S.S.; Tay-Yap, J. Cultural fits and misfits: Is ERP a universal solution? Commun. ACM 2000, 43, 47-51. [CrossRef]

7. Lozinsky, S. Enterprise-Wide Software Solutions. Integration Strategies and Practices; Addison-Wesley Information Technology Series; Addison-Wesley: Boston, MA, USA, 1998.

8. Nwankpa, J.K. ERP system usage and benefit: A model of antecedents and outcomes. Comput. Hum. Behav. 2015, 45, 335-344. [CrossRef]

9. Marabelli, M.; Newell, S. Absorptive Capacity and Enterprise Systems Implementation: The Role of Prior-Related Knowledge. Data Base Adv. Inf. Syst. 2019, 50, 111-131. [CrossRef]

10. Organ, D.W. Organizational Citizenship Behavior: The Good Soldier Syndrome; Lexington Books: Lexington, MA, USA, 1988.

11. Bostrom, R.P. Successful application of communication techniques to improve the systems development process. Inf. Manag. 1989, 16, 279-295. [CrossRef]

12. Blau, P. Exchange and Power in Social Life; Wiley: New York, NY, USA, 1964.

13. Kelley, H.H.; Thibaut, J.W. Interpersonal Relations: A Theory of Interdependence; John Wiley and Sons: New York, NY, USA, 1978.

14. Davis, J.M. Leveraging the IT competence of non-IS workers: Social exchange and the good corporate citizen. Eur. J. Inf. Syst. 2013, 22, 403-415. [CrossRef]

15. Smith, C.A.; Organ, D.; Near, J.P. Organizational citizenship behavior: Its nature and antecedents. J. Appl. Psychol. 1983, 68, 653-663. [CrossRef]

16. Becker, T.E.; Vance, R.J. Construct validity of three types of organizational citizenship behavior: An illustration of the direct product model with refinements. J. Manag. 1993, 19, 663-682. [CrossRef]

17. Mackenzie, S.B.; Podsakoff, O.M.; Fetter, R. Organizational citizenship behavior and objective productivity as determinants of managerial evaluations of salespersons' performance. Organ. Behav. Hum. Decis. Process. 1991, 50, 123-150. [CrossRef]

18. Van Dyne, L.; Graham, J.W.; Dienesch, R.M. Organizational citizenship behavior: Construct redefinition, measurement, and validation. Acad. Manag. J. 1994, 37, 765-802.

19. George, J.M.; Bettenhausen, K. Understanding prosocial behavior, sales performance, and turnover: A group-level analysis in a service context. J. Appl. Psychol. 1990, 75, 698-710. [CrossRef]

20. Podsakoff, P.M.; Mackenzie, S.B. Organizational citizenship behaviors and sales unit effectiveness. J. Mark. Res. 1994, 31, 351-363.

21. Morrison, E.W. Organizational citizenship behavior as a critical link between HRM practices and service quality. Hum. Resour. Manag. 1996, 35, 493-512. [CrossRef]

22. Yoon, M.H.; Suh, J. Organizational citizenship behaviors and service quality as external effectiveness of contact employees. J. Bus. Res. 2003, 56, 597-611. [CrossRef]

23. Chang, T.-W.; Chen, F.-F.; Luan, H.-D.; Chen, Y.-S. Effect of Green Organizational Identity, Green Shared Vision, and Organizational Citizenship Behavior for the Environment on Green Product Development Performance. Sustainability 2019, 11, 617. [CrossRef]

24. Stoffers, J.; van der Heijden, B.; Schrijver, I. Towards a Sustainable Model of Innovative Work Behaviors' Enhancement: The Mediating Role of Employability. Sustainability 2020, 12, 159. [CrossRef]

25. Cohen, W.; Levinthal, D. Absorptive capacity: A new perspective on learning and innovation. Adm. Sci. $Q$. 1990, 35, 128-152. [CrossRef] 
26. Zahra, S.A.; George, G. Absorptive capacity: A review, reconceptualization, and extension. Acad. Manag. Rev. 2002, 27, 185-203. [CrossRef]

27. Bower, G.H.; Hilgrad, E.R. Theories of Learning; Prentice Hall: Englewood Cliffs, NJ, USA, 1981.

28. Kim, L. The dynamics on Samsung's technological learning in semiconductors. Calif. Manag. Rev. 1997, 39, 86-100. [CrossRef]

29. Szulanski, G. Exploring internal stickiness: Impediments to the transfer of best practice within the firm. Strateg. Manag. J. 1996, 17, 27-43. [CrossRef]

30. Leonard-Barton, D. Wellsprings of Knowledge; Harvard Business School Press: Boston, MA, USA, 1995.

31. Park, J.H.; Suh, H.J.; Yang, H.D. Perceived absorptive capacity of individual users in performance of enterprise resource planning (ERP) usage: The case for Korean firms. Inf. Manag. 2007, 44, 300-312. [CrossRef]

32. Kim, L. Crisis construction and organizational learning: Capability building in catching-up at Hyundai Motor. Organ. Sci. 1998, 9, 506-521. [CrossRef]

33. Gao, S.; Yeoh, W.; Wong, S.F.; Scheepers, R. A literature analysis of the use of absorptive capacity construct in IS research. Int. J. Inf. Manag. 2017, 37, 36-42. [CrossRef]

34. Francalanci, C.; Morabito, V. IS integration and business performance: The mediation effect of organizational absorptive capacity in SMEs. J. Inf. Technol. 2008, 23, 297-312. [CrossRef]

35. Daghfous, A.; Belkhodja, O.; Ahmad, N. Understanding and managing knowledge transfer for customers in IT adoption. Inf. Technol. People 2018, 31, 428-454. [CrossRef]

36. Lee, S.C.; Lee, H.G. The importance of change management after ERP implementation an information capability perspective. In Proceedings of the ICIS 2004 Proceedings, Washington, DC, USA, 12-15 December 2004; p. 76.

37. Wang, E.T.; Lin, C.C.L.; Jiang, J.J.; Klein, G. Improving enterprise resource planning (ERP) fit to organizational process through knowledge transfer. Int. J. Inf. Manag. 2007, 27, 200-212. [CrossRef]

38. Ke, W.; Wei, K.K. Organizational culture and leadership in ERP implementation. Decis. Support Syst. 2008, 45, 208-218. [CrossRef]

39. Yoon, C. The effects of organizational citizenship behaviors on ERP system success. Comput. Hum. Behav. 2009, 25, 421-428. [CrossRef]

40. Saraf, N.; Liang, H.; Xue, Y.; Hu, Q. How does organisational absorptive capacity matter in the assimilation of enterprise information systems? Inf. Syst. J. 2013, 23, 245-267. [CrossRef]

41. Liu, L.; Feng, Y.; Hu, Q.; Huang, X. From transactional user to VIP: How organizational and cognitive factors affect ERP assimilation at individual level. Eur. J. Inf. Syst. 2011, 20, 186-200. [CrossRef]

42. Mayeh, M.; Ramayah, T.; Mishra, A. The role of absorptive capacity, communication and trust in ERP adoption. J. Syst. Softw. 2016, 119, 58-69. [CrossRef]

43. Nandi, M.L.; Vakkayil, J. Absorptive capacity and ERP assimilation: The influence of company ownership. Bus. Process Manag. J. 2018, 24, 695-715. [CrossRef]

44. Kankanhalli, A.; Tan, B.C.Y.; Wei, K.K. Contributing knowledge to electronic knowledge repositories: An empirical investigation. MIS Q. 2005, 29, 113-143. [CrossRef]

45. Bock, G.W.; Kim, Y.G. Breaking the myths of rewards: An exploratory study of attitudes about knowledge sharing. Inf. Resour. Manag. J. 2002, 15, 14-21. [CrossRef]

46. Ching, R.; Niehof, B. A proposed model of the effects of organizational citizenship behavior on sustained information technology innovations. In Proceedings of the AMCIS 2003 Proceedings, Tampa, FL, USA, 4-6 August 2003; p. 213.

47. Kusunoki, K.; Nonaka, I.; Nagata, A. Organizational capabilities in product development of Japanese firms: A conceptual framework and empirical findings. Organ. Sci. 1998, 9, 699-719. [CrossRef]

48. Gupta, A.K.; Wileman, D.L. Accelerating the development of technology-based new product. Calif. Manag. Rev. 1990, 32, 24-44. [CrossRef]

49. Madhavan, R.; Grover, R. From embedded knowledge to embodied knowledge: New product development as knowledge management. J. Mark. 1998, 62, 1-12. [CrossRef]

50. Meyers, P.W.; Wilemon, D. Learning in new technology development teams. J. Prod. Innov. Manag. 1989, 6, 79-88. [CrossRef]

51. Mowery, D.; Oxley, J.E.; Silverman, B.S. Strategic alliances and interfirm knowledge transfer. Strateg. Manag. J. 1996, 17, 77-92. [CrossRef] 
52. Boynton, A.C.; Zmud, R.W.; Jacobs, G.C. The influence of IT management practice on IT use in large organizations. MIS Q. 1994, 18, 299-320. [CrossRef]

53. Feng, Y.; Tam, K.Y. Gain and loss in system switching: A behavioral economics view to understand the joint effects of system usage performance on user satisfaction. In Proceedings of the PACIS 2013 Proceedings, Jeju Island, Korea, 18-22 June 2013; p. 276.

54. Hair, J.F.; Ringle, C.M.; Sarstedt, M. PLS-SEM: Indeed a silver bullet. J. Mark. Theory Pract. 2011, 19, $139-152$. [CrossRef]

55. Chin, W.W.; Marcolin, B.L.; Newsted, P.R. A partial least squares latent variable modeling approach for measuring interaction effects: Results from a Monte Carlo simulation study and an electronic-mail emotion/adoption study. Inf. Syst. Res. 2003, 14, 189-217. [CrossRef]

56. Anderson, J.C.; Gerbing, D.W. Structural equation modeling in practice: Review and recommended two-step approach. Psychol. Bull. 1988, 103, 411-423. [CrossRef]

57. Thornton, S.C.; Henneberg, S.C.; Naud, P. Conceptualizing and validating organizational networking as a second-order formative construct. Ind. Mark. Manag. 2014, 43, 951-966. [CrossRef]

58. Nunnally, J.C.; Bernstein, I.H.; Berge, J.M.T. Psychometric Theory; McGraw-Hill: New York, NY, USA, 1967.

59. Hair, J.F.; Anderson, R.E.; Tatham, R.L.; Black, W.C. Multivariate Data Analysis; Prentice Hall: Upper Saddle River, NJ, USA, 1998.

60. Bagozzi, R.P.; Yi, Y. On evaluation of structural equation model. J. Acad. Mark. Sci. 1988, 16, 74-94. [CrossRef]

61. Fornell, C.; Larcker, D.F. Evaluating structural equation models with unobservable variables and measurement error. J. Mark. Res. 1981, 18, 39-50. [CrossRef]

62. Podsakoff, P.M.; Organ, D.W. Self-reports in organizational research: Problems and prospects. J. Manag. 1986, 12, 531-544. [CrossRef]

63. Liang, H.; Saraf, N.; Hu, Q.; Xue, Y. Assimilation of enterprise systems: The effect of institutional pressures and the mediating role of top management. MIS Q. 2007, 31, 59-87. [CrossRef]

64. Baron, R.M.; Kenny, D.A. The moderator-mediator variable distinction in social psychological research: Conceptual, strategic, and statistical considerations. J. Personal. Soc. Psychol. 1986, 51, 1173-1182. [CrossRef]

65. Sobel, M.E. Asymptotic confidence intervals for indirect effects in structural equation models. Sociol. Methodol. 1982, 13, 290-312. [CrossRef]

66. Subramani, M. How do suppliers benefit from information technology use in supply chain relationships? MIS Q. 2004, 28, 45-73. [CrossRef]

67. Nelson, M.J.; Cooprider, J.G. The contribution of shared knowledge to IS group performance. MIS Q. 1996, 20, 409-432. [CrossRef]

68. Gefen, D.; Keil, M. The impact of developer responsiveness on perceptions of usefulness and ease of use: An extension of the technology acceptance model. Data Base Adv. Inf. Syst. 1998, 29, 35-49. [CrossRef]

69. Kogut, B.; Zander, U. Knowledge of the firm, combinative capabilities, and the replication of technology. Organ. Sci. 1992, 3, 383-397. [CrossRef]

70. Lin, H.F. Effects of extrinsic and intrinsic motivation on employee knowledge sharing intentions. J. Inf. Sci. 2007, 33, 135-149. [CrossRef]

71. Pyun, J. Can ERP improve business performance? CIO Perspect. 2002, 2, 1-78.

72. Tanriverdi, H. Information technology relatedness, knowledge management capability, and performance of multibusiness firms. MIS Q. 2005, 29, 311-334. [CrossRef]

(C) 2020 by the authors. Licensee MDPI, Basel, Switzerland. This article is an open access article distributed under the terms and conditions of the Creative Commons Attribution (CC BY) license (http://creativecommons.org/licenses/by/4.0/). 